Article

\title{
Antifungal Activity of Extracts and Prenylated Coumarins Isolated from Baccharis darwinii Hook \& Arn. (Asteraceae)
}

Rita R. Kurdelas ${ }^{1}$, Beatriz Lima ${ }^{2}$, Alejandro Tapia ${ }^{2}$, Gabriela Egly Feresin ${ }^{2}$, Manuel Gonzalez Sierra $^{3}$, María Victoria Rodríguez ${ }^{3}$, Susana Zacchino ${ }^{3}$, Ricardo D. Enriz ${ }^{4}$ and Monica L. Freile ${ }^{1, *}$

1 Laboratorio de Productos Naturales Patagónicos (LAPRONAP), Facultad de Ciencias Naturales, Universidad Nacional de la Patagonia San Juan Bosco, Km 4, CP 9000, Comodoro Rivadavia, Chubut, Argentina; E-Mail: rkurdelas@unpata.edu.ar (R.R.K.)

2 Instituto de Biotecnología - Instituto de Ciencias Básicas, Universidad Nacional de San Juan, Av. Libertador General San Martín 1109 (O), CP5400, San Juan, Argentina;

E-Mails: atapia@unsj.edu.ar (A.T.); blima@unsj.edu.ar (B.L.); gferesin@unsj.edu.ar (G.E.F.)

3 Facultad de Ciencias Bioquímicas y Farmacéuticas, Farmacognosia y Biología Vegetal.

Universidad Nacional de Rosario, Suipacha 531, CP2000, Rosario, Argentina;

E-Mail: szaabgil@citynet.net.ar (S.Z.)

4 Facultad de Química, Bioquímica y Farmacia. Universidad Nacional de San Luis, Chacabuco 917, CP5700, San Luis, Argentina; E-Mail: denriz@unsl.edu.ar (R.D.E.)

* Author to whom correspondence should be addressed; E-Mail: mfreile@unpata.edu.ar; Tel.: +54-297-4550339; Fax: +54-297-4550339.

Received: 17 June 2010; in revised form: 1 July 2010 / Accepted: 7 July 2010 /

Published: 13 July 2010

Abstract: The petroleum ether extract of Baccharis darwinii showed activity against Cryptococcus neoformans and dermatophytes. Bioactivity-guided fractionation of Baccharis darwinii has resulted in the isolation of three coumarins: 5'-hydroxy aurapten (anisocoumarin H, 1), aurapten (7-geranyloxycoumarin, 2) and 5'-oxoaurapten (diversinin, 3). The structures of these compounds were characterized by spectroscopic methods. These compounds were evaluated for their antimicrobial activity against a panel of each, bacteria and fungi. Compound $\mathbf{3}$ showed the best activities against Microsporum gypseum, Trichophyton rubrum and Trichophyton mentagrophytes with MICs $=15.6 \mu \mathrm{g} / \mathrm{mL}$, followed by compound 1 whose MICs against the same fungi were $62.5 \mu \mathrm{g} / \mathrm{mL}$. In addition they showed fungicidal rather than fungistatic activity. Both compounds showed moderate 
activity (MICs $=125 \mu \mathrm{g} / \mathrm{mL}$ ) against Cryptococcus neoformans. This is the first report of the presence of compound $\mathbf{1}$ in B. darwinii.

Keywords: Baccharis darwinii; Asteraceae; prenylated coumarins; auraptene; antimicrobial activity

\section{Introduction}

Currently, medicinal plants are widely used as home remedies or as alternative treatments by both rural and urban inhabitants in developing countries [1], which can be explained in part by the high cost of industrialized medicine. In turn, many extracts from plants have shown biological activities of interest, which justifies the search of potentially active compounds in them.

A matter of concern in public health in the last decades is the increasing resistance of bacteria and fungus to antimicrobial drugs and the growing number of immunocompromised patients undergoing fatal fungal infections, since the available antifungals are scarce, sometimes ineffective and not always safe.

The genus Baccharis L. possesses the highest number of species (between 400 and 500) within the Asteraceae family [2]. It was found only in American countries from the south of United States to the austral end of Argentina and Chile, occupying a great variety of environments. In the Argentine Republic, it is represented by 96 species [2], and among them, Baccharis darwinii, commonly known as "chilca", can be found in the far south of South America that is, in the arid Patagonia region of Argentina .

Several species of Baccharis genus are used in traditional medicine [3,4] for different ailments. Some species, known as “carquejas” (B. trimera, B. crispa, etc.) are used against hepatic disorders. Another species, known as "mio-mio" (B. coridifolia) is poisonous for livestock [5], while another, "mata-trigo" (B. gilliesii), is an invader of cultures.

Studies on the biological activities of species of this genus have shown antimicrobial, antioxidant, anti-inflammatory and antifeedant activities [6-17]. Regarding the chemical constituents found in the genus, flavonoids and terpenoids are the most frequently reported [17-20]. Regarding $B$. darwinii, the presence of $\beta$-farnesene, aurapten, 5'-oxoaurapten, and 6',7'-epoxy- and 6',7'-dihydroxyaurapten were reported by Zdero et al. in a sample collected in the Argentinean Neuquén province [21]. Nevertheless, to the best of our knowledge there are no reports on the biological activities of Baccharis darwinii. We report here the antimicrobial activity of crude extracts of this plant collected in Chubut province, a southernmost province of Argentina, and the bioassay-guided fractionation of its most active extract which led to the isolation of the main compounds responsible for the activity.

\section{Results and Discussion}

In the first step of our work, we evaluated the antimicrobial (antibacterial and antifungal) activity of the petroleum ether (PE), dichloromethane (DCM) and methanol (MeOH) extracts from aerial parts of Baccharis darwinii. Regarding antibacterial activity of the different extracts, $\mathrm{MeOH}$ did not show any activity (MIC > 1,000 $\mu \mathrm{g} / \mathrm{mL}$ ), PE showed only marginal activity (MIE $1,000 \mu \mathrm{g} / \mathrm{mL}$ ) and DCM 
extract showed a very low activity against only two bacteria (MIC $=750 \mu \mathrm{g} / \mathrm{mL}$ ) and marginal or null activity against the rest of bacteria of the panel.

In contrast, the three extracts showed better antifungal activities, mainly against dermatophytes and, in addition, they were shown to possess not only fungistatic but also fungicidal capacity (Table 1). Nevertheless, some differences could be observed among the activity of the three extracts (Table 1): the $\mathrm{PE}$ and $\mathrm{MeOH}$ extracts were the most active extracts mainly against $C$. neoformans. Between them, $\mathrm{PE}$ extract showed four-fold higher potency than $\mathrm{MeOH}$ extract against the same fungi. Among the different extracts, PE is of great interest since it showed a selective and good activity against $C$. neoformans and dermatophytes. On the basis of these results, PE was submitted to fractionation guided by antifungal activity as described in the Experimental section.

Table1. Antifungal and antibacterial activity to Baccharis darwinii extracts (MIC/MFC, $\mu \mathrm{g} / \mathrm{mL}$ ).

\begin{tabular}{|l|c|c|c|c|c|c|}
\hline Microorganisms & \multicolumn{3}{|c|}{ Extracts } & \multicolumn{3}{c|}{ Reference drugs } \\
\hline Fungus & PE & DCM & MeOH & Amp B & Ket & Terb \\
\hline Candida albicans ATCC 10231 & $>1,000$ & $>1,000$ & $>1,000$ & 1 & 0.5 & - \\
\hline Candida tropicalis C 131 2000 & $>1,000$ & $>1,000$ & $>1,000$ & 0.5 & 0.125 & - \\
\hline Saccharomyces cerevisiae ATCC 9763 & $>1,000$ & $>1,000$ & $>1,000$ & 0.5 & 0.5 & - \\
\hline Cryptococcus neoformans ATCC 32264 & $125 / 250$ & $>1,000$ & $500 / 1,000$ & 0.25 & 0.25 & - \\
\hline Aspergillus flavus ATCC 9170 & $>1,000$ & $>1,000$ & $>1,000$ & 0.5 & 0.125 & - \\
\hline Aspergillus fumigatus ATCC 26934 & $>1,000$ & $>1,000$ & $>1,000$ & 0.5 & 0.25 & - \\
\hline Aspergillus niger ATCC 9029 & $>1,000$ & $>1,000$ & $>1,000$ & 0.5 & 0.5 & \\
\hline Microsporum gypseum C 115 2000 & $125 / 125$ & $1,000 / 1,000$ & $500 / 500$ & 0.125 & 0.05 & 0.04 \\
\hline Trichophyton rubrum C 113 2000 & $62.5 / 125$ & $500 / 1,000$ & $250 / 1,000$ & 0.075 & 0.025 & 0.025 \\
\hline Trichophyton mentagrophytes ATCC 9972 & $62.5 / 125$ & $500 / 1,000$ & $250 / 500$ & 0.075 & 0.025 & 0.04 \\
\hline
\end{tabular}

(*) Reference substances: Amp B: Amphotericin B, Ket: Ketoconazole, Terb: Terbinafine.

The nine sub-fractions obtained from PE extract (I-IX) were evaluated for antifungal properties against the same panel used for the crude extracts. Results (Table 2) showed that the best activity was displayed by sub-fraction VI against dermatophytes (MIC and MFC $=62.5 \mu \mathrm{g} / \mathrm{mL}$ ). From this subfraction for successive fractionations, three known coumarins: 5'-hydroxyaurapten (anisocoumarin $\mathrm{H}$, 1), aurapten (7-geranyloxycoumarin, 2) and 5'-oxoaurapten (diversinin, 3) were isolated and their antifungal activities were evaluated. Of these, $\mathbf{1}$ has not been reported previously in $B$. darwinii while $\mathbf{2}$ and $\mathbf{3}$ have been reported previously in this plant [21]. The compounds were identified by comparison of their NMR data with literature vales (see Experimental). The corresponding structures are shown in Figure 1.

It is interesting to note that two of these coumarins, $\mathbf{1}$ and $\mathbf{3}$, displayed antifungal activity against $C$. neoformans and dermatophytes (Table 2) and therefore both compounds would be the responsible for the antifungal activity observed in the PE extract of $B$. darwinii. Compound $\mathbf{3}$ possess a high fungistatic activity against the three dermatophytes tested, with MICs $=15.6 \mu \mathrm{g} / \mathrm{mL}$ and a fungicide capacity. This result is very interesting since T. rubrum and T. mentagrophytes are responsible for approximately $80-93 \%$ of chronic and recurrent dermatophytes infections in human beings. They are the ethiological agent of tinea unguium (producer of invasive nail infections), tinea manuum (palmar and interdigital areas of the hand infections) and tinea pedis (athlete's foot), the last one being the most 
prevalent fungal infection in developed countries, and the first one accounting for $50 \%$ and $90 \%$ of all fingernail and toenail infections respectively [22].

Table 2. In vitro evaluation of the antifungal activity of different fractions resulted from Sephadex percolation of PE extracts and compounds 1-3 from B. darwinii (MIC/MFC values are given in $\mu \mathrm{g} / \mathrm{mL}$ ).

\begin{tabular}{|c|c|c|c|c|c|c|c|}
\hline Seph PE Fractions & $\boldsymbol{C a}$ & $\boldsymbol{C t}$ & $\boldsymbol{S c}$ & $\boldsymbol{C n}$ & $\boldsymbol{M g}$ & $\boldsymbol{T r}$ & $\boldsymbol{T m}$ \\
\hline Seph PE I-III & $>250$ & $>250$ & $>250$ & $>250$ & $>250$ & $>250$ & $>250$ \\
\hline Seph PE IV & $>250$ & $>250$ & $>250$ & $>250$ & $250 / 250$ & $250 / 250$ & $250 / 250$ \\
\hline Seph PE V & $>250$ & $>250$ & $>250$ & $250 />250$ & $62.5 / 62.5$ & $62.5 / 125$ & $62.5 / 125$ \\
\hline Seph PE VI & $>250$ & $>250$ & $>250$ & $250 />250$ & $62.5 / 62.5$ & $62.5 / 62.5$ & $62.5 / 62.5$ \\
\hline Seph PE VII & $>250$ & $>250$ & $>250$ & $250 />250$ & $125 / 250$ & $125 / 250$ & $125 / 250$ \\
\hline Seph PE VIII & $>250$ & $>250$ & $>250$ & $250 />250$ & $250 / 250$ & $250 />250$ & $250 />250$ \\
\hline Seph PE IX & $>250$ & $>250$ & $>250$ & $>250$ & $>250$ & $>250$ & $>250$ \\
\hline Compounds & & & & & & & \\
\hline $\mathbf{1}$ & $>250$ & $>250$ & $>250$ & 125 & $62.5 / 125$ & $62.5 / 62.5$ & $62.5 / 62.5$ \\
\hline $\mathbf{2}$ & $>250$ & $>250$ & $>250$ & $>250$ & $>250$ & $>250$ & $>250$ \\
\hline $\mathbf{3}$ & $>250$ & $>250$ & $>250$ & 125 & $15.6 / 125$ & $15.6 / 125$ & $15.6 / 125$ \\
\hline Reference drugs & & & & & & & 0.07 \\
\hline Amphotericin B & 0.25 & 0.25 & 1 & 0.50 & 0.12 & 0.07 & 0.02 \\
\hline Ketoconazole & 0.25 & 0.25 & 0.50 & 0.50 & 0.04 & 0.02 & 0.04 \\
\hline Terbinafine & & & & & 0.04 & 0.01 & 0.04 \\
\hline
\end{tabular}

Ca: Candida albicans ATCC 10231; Ct: Candida tropicalis C 131; Sc: Saccharomyces cerevisiae ATCC 9763; Cn: Cryptococcus neoformans ATCC 32264; Mg: Microsporum gypseum C 115; Tr: Trichophyton rubrum C113; Tm: Trichophyton mentagrophytes ATCC 9972.

Figure 1. Structures of compounds 1-3.<smiles>CC(C)=CC(O)CC(C)=CCOc1ccc2ccc(=O)oc2c1</smiles>

1<smiles>CC(C)=CC(=O)C/C(C)=C\COc1ccc2ccc(=O)oc2c1</smiles><smiles>CC(C)=CCC/C(C)=C\COc1ccc2ccc(=O)oc2c1</smiles>

2

In turn, although the activity displayed by $\mathbf{1}$ and $\mathbf{3}$ against $C$. neoformans (MIC $=125 \mu \mathrm{g} / \mathrm{mL}$ ) is moderate, it is worthy to take into account that $C$. neoformans remains an important life-threatening 
complication for immunocompromised hosts, particularly for patients who have undergone transplantation of solid organs and, therefore, new compounds acting against this fungus are highly welcome [23]. The antimicrobial activity is considered very interesting in the case of MICs < $100 \mu \mathrm{g}$ $\mathrm{mL}^{-1}$ for extracts and $10 \mu \mathrm{g} \mathrm{mL}^{-1}$ for isolated compounds [24]. Another interesting contribution of this work is that, since the three coumarins have been previously isolated from other species, such as anisocoumarin H (1) in Clausena anisata [25] and Notopterygium forbesii [26]; auraptene (2) in Ferulago capillaris [27], Paliurus ramosissimus [28]; diversinin (3) in Ferula diversivittata [29], this work encourages the beginning of antifungal studies of these species in order to evaluate their antifungal potentiality.

\section{Experimental}

\subsection{General}

IR spectra were recorded in a FTIR Shimadzu Prestige-21 instrument; 1D and 2D NMR spectra were recorded using a Bruker Avance 300 in deuterated chloroform solutions, using standard Bruker software. GC-MS were run in a Perkin Elmer Autosystem XL Gas Chromatograph coupled to a Turbo Mass Spectrometer. Column: SE-30, $25 \mathrm{~m} \times 0.22 \mathrm{~mm}$ ID, Scientific Glass Engineering (Ringwood, Victoria, Australia).

\subsection{Plant material}

Aerial parts of Baccharis darwinii were collected at Comodoro Rivadavia, Chubut Province, Argentina at $45^{\circ} 48^{\prime} 34.5^{\prime \prime}$ Latitude (S) and 67 $26^{\prime} 44^{\prime \prime}$ Longitude (O) in October 2007. The plant was identified by Prof. María Elena Arce, FCN, UNPSJB. A voucher specimen was deposited at Herbario Regional Patagónico (HRP 6154), Comodoro Rivadavia, Chubut, Argentina.

\subsection{Extraction}

The dried powdered aerial parts (450 g) were extracted successively with petroleum ether (PE), dichloromethane $(\mathrm{DCM})$ and methanol $(\mathrm{MeOH})$ at room temperature $(3 \times 1,000 \mathrm{~mL}$, for $96 \mathrm{~h}$ each time). After evaporation to dryness under reduced pressure, PE, DCM and $\mathrm{MeOH}$ extracts were obtained in yields (w/w in terms of dry starting material) of $3.46 \%, 2.26 \%$ and $14,14 \%$, respectively.

\subsection{Isolation}

A representative sample from PE bioactive extract (13.13 g) was applied to a Sephadex LH-20 column (column length $37 \mathrm{~cm}$, diameter $4 \mathrm{~cm}$ ) equilibrated with: PE:MeOH:CHCl 3 (2:1:1). After TLC comparison (silica gel, EtOAc:PE 2:8, as the mobile phase; detection under UV light followed by spraying with $p$-anisaldehyde), nine fractions were obtained: I: (0.2076 g), II: 1.1049 g, III: 1.2438 g, IV: 2.6301 g, V: 0.9964 g, VI: 3.6209 g, VII: 0.4913 g, VIII: 0.0180 g, IX: 0.0936 g. 


\subsubsection{Pooled fraction VI}

Fraction VI (3 g) was applied to a Sephadex LH-20 column (column length $37 \mathrm{~cm}$, diameter $4 \mathrm{~cm}$ ) equilibrated with: PE:MeOH: $\mathrm{CHCl}_{3}$ (2:1:1). After TLC comparison (silica gel, EtOAc:PE 2:8 as the mobile phase; detection under UV light followed by spraying with $p$-anisaldehyde), fractions were combined affording fifteen new fraction: $\mathrm{VI}_{1}: 0.0022 \mathrm{~g}, \mathrm{VI}_{2}: 0.0034 \mathrm{~g}, \mathrm{VI}_{3}: 0.0113 \mathrm{~g}, \mathrm{VI}_{4}: 0.0209 \mathrm{~g}$, $\mathrm{VI}_{5}: 0.0436 \mathrm{~g}, \mathrm{VI}_{6}: 0.1155 \mathrm{~g}, \mathrm{VI}_{7}: 0.2904 \mathrm{~g}, \mathrm{VI}_{8}: 0.4154 \mathrm{~g}, \mathrm{VI}_{9}: 0.4587 \mathrm{~g}, \mathrm{VI}_{10}: 0.4793 \mathrm{~g}, \mathrm{VI}_{11}: 0.4424$ g, $\mathrm{VI}_{12}: 0.3260 \mathrm{~g}, \mathrm{VI}_{13}: 0.1543 \mathrm{~g}, \mathrm{VI}_{14}: 0.1015 \mathrm{~g}, \mathrm{VI}_{15}: 0.091 \mathrm{~g}$. From fractions $\mathrm{VI}_{12}-\mathrm{VI}_{15}$ pure compound 1 (91.6 mg) was obtained.

The potent bioactive antifungal fractions $\mathrm{VI}_{7}-\mathrm{VI}_{11}(749.2 \mathrm{mg})$ were applied onto a medium pressure chromatography column (MPCC, column length $60 \mathrm{~cm}$, diameter $2 \mathrm{~cm}$ ) containing $75 \mathrm{~g}$ silica gel (0.063-0.2 mesh, Merck 60) and eluted with $150 \mathrm{~mL}$ of cyclohexane-EtOAc 100:100 v/v. Some 350 fractions of $10 \mathrm{~mL}$ each were obtained. From fractions 44-64 pure compound 2 (72.6 mg) was obtained whereas from fractions 150-158 yielded mainly compound 3 (100.9 mg).

\subsection{Isolated compounds}

7-(5-Hydroxy-3,7-dimethylocta-2,6-dienyloxy)-chromen-2-one (5'-hydroxy aurapten, 1). The NMR data were in agreement with those reported by Ngadjui et al. [25].

7-(3,7-Dimethylocta-2,6-dienyloxy)-chromen-2-one (aurapten, 2). The NMR data were in agreement with those reported by Zdero et al. [21].

7-(3,7-Dimethyl-5-oxoocta-2,6-dienyloxy)-chromen-2-one (5'-oxoaurapten, 3). The NMR data were in agreement with those reported by Zdero et al. [21].

\subsection{Antimicrobial activity}

\subsubsection{Microorganisms and media}

For the antibacterial evaluation, strains from the American Type Culture Collection (ATCC) Rockville MD (USA), Malbrán Institute (MI), Pasteur Institute (PI) and from the Laboratorio de Microbiología (LM, Facultad de Ciencias Médicas, Universidad Nacional de Cuyo, Mendoza,

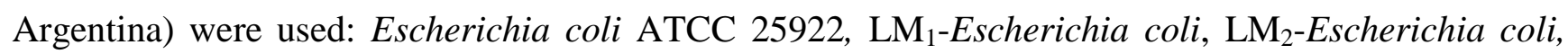
Pseudomonas aeruginosa ATCC 27853, LM-Salmonella sp., MI-Salmonella enteritidis, PI-Yersinia enterocolítica, Staphylococcus aureus methicillin-sensitive ATCC 29213 and Staphylococcus aureus methicillin-resistant ATCC 43300. Bacteria were grown on Müeller-Hinton agar medium.

For the antifungal evaluation, strains from the American Type Culture Collection (ATCC), Rockville, MD, USA and CEREMIC (C), Centro de Referencia en Micología, Facultad de Ciencias Bioquímicas y Farmacéuticas, Suipacha 531, 2000 Rosario, Argentina, were used: Candida albicans ATCC10231, Candida tropicalis C131, Saccharomyces cerevisiae ATCC9763, Cryptococcus neoformans ATCC32264, Aspergillus flavus ATCC9170, Aspergillus fumigatus ATTC26934, Aspergillus niger ATCC9029, Trichophyton rubrum C110, Trichophyton mentagrophytes ATCC9972 and Microsporum gypseum C115. Strains were grown on Sabouraud-chloramphenicol agar slants for 
$48 \mathrm{~h}$ at $30^{\circ} \mathrm{C}$, maintained on slopes of Sabouraud-dextrose agar (SDA, Oxoid) and sub-cultured every 15 days to prevent pleomorphic transformations. Inocula were obtained according to reported procedures [30] and adjusted to $1-5 \times 10^{3}$ cells/spores with colony forming units (CFU) $/ \mathrm{mL}$

\subsubsection{Antibacterial susceptibility testing}

Cultures less than $30 \mathrm{~h}$ old were touched with a loop and transferred to sterile Mueller-Hinton broth. The broth was incubated at $37^{\circ} \mathrm{C}$ until the growth reaches turbidity equal to, or greater than that of 0.5 Mc Farland standards. The culture was adjusted with sterile physiological solution to give final organism density of $5 \times 10^{5} \mathrm{CFU} / \mathrm{mL}$ [31, 32]. The antibacterial activity was evaluated with the agar dilution method using Mueller Hinton agar medium for Gram (+) and Gram (-) bacteria. Stock solutions of the compounds/extracts in DMSO were diluted to give serial two-fold dilutions that were added to each medium resulting in concentrations ranging from 10 to $1,000 \mu \mathrm{g} / \mathrm{mL}$. The final concentration of DMSO in the assay did not exceed 1\%. The antimicrobial agent cefotaxime (Argentia Pharmaceutica) was included in the assays as positive control. The plates were incubated for $24 \mathrm{~h}$ at $37{ }^{\circ} \mathrm{C}$. Minimum Inhibitory Concentration (MIC) was defined as the lowest compounds/extracts concentration showing no visible bacterial growth after incubation time. Tests were carried out in triplicate. Extracts and compounds with MICs $\leq 250 \mu \mathrm{g} / \mathrm{mL}$ were considered of interest.

\subsubsection{Antifungal susceptibility testing}

Minimum Inhibitory Concentration (MIC) of each extract or compound was determined by using broth microdilution techniques according to the guidelines of the Clinical and Laboratory Standards Institute (CLSI, formerly National Committee for Clinical and Laboratory Standards, NCCLS) for yeasts (M27-A2) and for filamentous fungi (M 38 A), [30]. MIC values were determined in RPMI1640 (Sigma, St Louis, MO, USA) buffered to $\mathrm{pH} 7.0$ with MOPS. Microtiter trays were incubated at $35{ }^{\circ} \mathrm{C}$ for yeasts and hialohyphomycetes and at $28-30{ }^{\circ} \mathrm{C}$ for dermatophyte strains in a moist, dark chamber. MICs were visually recorded at $48 \mathrm{~h}$ for yeasts, and at a time according to the control fungus growth, for the rest of fungi. Extracts with MICs $\leq 1,000 \mu \mathrm{g} / \mathrm{mL}$ and sub-extracts and compounds with MICs $\leq 250 \mu \mathrm{g} / \mathrm{mL}$ were considered active.

For the assay, stock solutions of pure compounds were two-fold diluted with RPMI from 1,000 or $250 \mu \mathrm{g} / \mathrm{mL}$ to 0.98 (final volume $=100 \mu \mathrm{L}$ ) and a final DMSO concentration $\leq 1 \%$. A volume of 100 $\mu \mathrm{L}$ of inoculum suspension was added to each well with the exception of the sterility control where sterile water was added to the well instead. Ketoconazole (Sigma Chem. Co.), terbinafine (Novartis, Argentina) and amphotericin B (Sigma Chem. Co.), were used as positive controls. Endpoints were defined as the lowest concentration of drug resulting in total inhibition ( $\left.\mathrm{MIC}_{100}\right)$ of visual growth compared to the growth in the control wells containing no antifungal.

The Minimum Fungicidal Concentration (MFC) of each extract or compound was determined as follows: After determining the MIC, an aliquot of $5 \mu \mathrm{L}$ sample was withdrawn from each clear well of the microtiter tray and plated onto a 150-mm RPMI-1640 agar plate buffered with MOPS (Remel, Lenexa, Kans.). Inoculated plates were incubated at $30{ }^{\circ} \mathrm{C}$, and MFCs were recorded after $48 \mathrm{~h}$. The MFC was defined as the lowest concentration of each compound that resulted in total inhibition of visible growth in these plates. 


\section{Conclusions}

Phytochemical study of $B$. darwinii extracts, bioguided by the antifungal assay, led to the isolation of the known prenylated coumarins 5'-hydroxyaurapten (1), aurapten (2) and 5'-oxoaurapten (3). This is the first report of the presence of compound $\mathbf{1}$ in B. darwinii. Among the three isolated compounds compound 3 showed the best activities against M. gypseum, T. rubrum and T. mentagrophytes with MICs $=15.6 \mu \mathrm{g} / \mathrm{mL}$, followed by compound 1 whose MICs against the same fungi were $62.5 \mu \mathrm{g} / \mathrm{mL}$. In addition their activity was shown to be fungicidal rather than fungistatic. Both compounds showed moderate activity (MICs $=125 \mu \mathrm{g} / \mathrm{mL}$ ) against $C$. neoformans.

\section{Acknowledgements}

The authors are grateful to the Agencia Nacional de Promoción Científica y Tecnológica de la Argentina (PICT 995 - PICT 1494) for financial support, to SECyT- Universidad Nacional de la Patagonia S.J.B., Chubut; Universidad Nacional de Rosario; CICITCA, Universidad Nacional de San Juan, Argentina. B.L. and M.V.R. are fellowships of CONICET. G.E.F. and R.D.E. are researchers from CONICET, Argentina.

\section{References and notes}

1. Brandão, M.G.L.; Zanetti, N.N.S.; Oliveira, P.; Grael, C.F.F.; Santos, A.C.P.; Monte-Mór, R.L.M. Brazilian medicinal plants described by 19th century European naturalists and in the Official Pharmacopoeia. J. Ethnopharmacol. 2008, 120, 141-148.

2. Giuliano, D.A. Clasificación infragenérica de las especies argentinas de Baccharis (Asteraceae, Astereae). Darwiniana 2001, 39, 131-154.

3. Gupta, M.P., Ed. 270 Plantas Medicinales Iberoamericanas; CYTED and Convenio Andres Bello: Santafé de Bogotá, Colombia, 1995; pp. 73-84.

4. Soicke, H.; Leng-Peschlow, E. Characterization of flavonoids from Baccharis trimera and their antihepatotoxic properties. Planta Med. 1987, 53, 37-39.

5. Jarvis, B.B.; Wang, S.; Cox, C.; Rao, M.M.; Philip, V.; Varaschin, M.S.; Barros, C.S. Brazilian Baccharis toxins: livestock poisoning and the isolation of macrocyclic trichothecene glucosides. Nat. Toxins. 1996, 4, 58-71.

6. Abad, M.J.; Bessa, A.L.; Ballarin, B.; Aragón, O.; Gonzales, E.; Bermejo, P. Anti-inflammatory activity of four Bolivian Baccharis species (Compositae). J. Ethnopharmacol. 2006, 103, 338-344.

7. Feresin, G.; Tapia, A.; López, S.; Zacchino, S. Antimicrobial activity of plants used in traditional medicine of San Juan province, Argentine. J. Ethnopharmacol. 2001, 78, 103-107.

8. Feresin, G.E.; Tapia, A.; Gimenez, A.; Gutierrez Ravelo, A.; Zacchino, S.; Sortino, M.; SchmedaHirschmann, G. Constituents of the Argentinian medicinal plant Baccharis grisebachii and their antimicrobial activity. J. Ethnopharmacol. 2003, 89, 73-80.

9. Hadad, M.; Zygadlo, J.A.; Lima, B.; Derita, M.; Feresin, G.E.; Zacchino, S.A.; Tapia, A. Chemical composition and antimicrobial activity of essential oil from Baccharis grisebachii Hieron (Asteraceae). J. Chil. Chem. Soc. 2007, 52, 1186-1189. 
10. Morales, G.; Paredes, A.; Sierra, P.; Loyola, L. Antimicrobial activity of three Baccharis species used in the traditional medicine of northern Chile. Molecules 2008, 13, 790-794.

11. Tapia, A.; Rodriguez, J.; Theoduloz, C.; Lopez, S.; Feresin, G.; Schmeda-Hirschmann, G. Free radical scavengers and antioxidants from Baccharis grisebachii. J. Ethnopharmacol. 2004, 95, 155-161.

12. Mongelli, E.; Desmarchelier, C.; Rodriguez Talou, J.; Coussio, J.; Ciccia, G. In vitro antioxidant and cytotoxic activity of extracts of Baccharis coridifolia DC. J. Ethnopharmacol. 1997, 58, 157-163.

13. Parejo, I.; Valadomat, F.; Bastida, J.; Rosas-Romero, A.; Saavedra, A.; Murcia, M.A.; Jiménez, A.M.; Codina, C. Investigation of Bolivian plant extracts for their radical scavenging activity and antioxidant activity. Life Sci. 2003, 73, 1667-1681.

14. Rojas, J.; Velasco, J.; Rojas, L.; Diaz, T.; Carmona, J.; Morales, A. Chemical composition and antibacterial activity of the essential oil of Baccharis latifolia Pers. And B. prunifolia H. B. \&K. (Asteraceae). Nat. Prod. Commun. 2007, 12, 1245-1248.

15. Enriz, R.D.; Baldoni, H.A.; Jauregui, E.A.; Sosa, M.E.; Tonn, C.E.; Giordano, O.S. StructureActivity relationship of clerodane Diterpenoids acting as antifeedant agents. J. Agric. Food Chem. 1994, 42, 2958-2963.

16. Enriz, R.D.; Baldoni, H.A.; Zamora, M.A.; Jáuregui, E.A.; Sosa, M.E.; Tonn, C.E.; Luco, J.M.; Gordaliza, M. Structure-Antifeedant Activity Relationship of Clerodane Diterpenoids. Comparative Study with Withanolides and Azadirachtin. J. Agric. Food Chem. 2000, 48, 1384-1392.

17. Cifuente, D.A.; Borkowski, E.J.; Sosa, M.E.; Gianello, J.C.; Giiordano, O.S.; Tonn, C.E. Clerodane diterpenes from Baccharis sagittalis: insect antifeedant activity. Phytochemistry 2002, 61, 899-905.

18. Dos Santos, D.; Fukui, M.; Nanayakkara, N.; Khan, S.; Sousa, J.; Bastos, J.; Andrade, S.; da Silva Flho, A.; Quintao N. Anti-inflammatory and antinociceptive effects of Baccharis dracunculifolia DC (Asteraceae) in different experimental models. J. Ethnopharmacol. 2010, 127, 543-550.

19. Simoes-Pires, C.A.; Queiroz, E.F. Henriques AT, Hostettmann K. Isolation and on-line identification of antioxidant compounds from three Baccharis species by HPLC-UV-MS/MS with post-column derivatisation. Phytochem. Anal. 2005, 16, 307-314.

20. Wachter, G.A.; Montenegro, G.; Timmermann, B.N. Diterpenoids from Baccharis pingraea. J. Nat. Prod. 1999, 62, 307-308.

21. Zdero, C.; Bohlman, R.M.; King, M.; Robinson, H. Diterpene glycosides and other constituents from Argentinian Baccharis species. Phytochemistry 1986, 25, 2841-2855.

22. Weitzman, R.; Summerbell, I. The dermatophytes. Clin. Microb. Rev. 1995, 8, 240-256.

23. Singh, N. Treatment of opportunistic mycoses: how long is long enough? Lancet Infect. Dis. 2003, 3, 703-708.

24. Ríos, J.L.; Recio, M.C. Medicinal plants and antimicrobial activity. J. Ethnopharmacol. 2005, 100, 80-84.

25. Ngadjui, B.; Ayafor, J.; Sondengam, B.; Connolly, J. Coumarins from Clausena anisata. Phytochemistry 1989, 28, 585-589. 
26. Ma, Z.; Xu, W.; Liu-Chen, L.-Y.; Lee, D.Y.W. Novel coumarin glycoside and phenethyl vanillate from Notopterygium forbesii and their binding affinities for opioid and dopamine receptors. Bioorg. Med. Chem. 2008, 16, 3218-3223.

27. Jimenez, B.; Grande, M.C.; Anaya, J.; Torres, P.; Grande M. Coumarins from Ferulago capillaris and F. brachyloba. Phytochemistry 2000, 53, 1025-1031.

28. Yu, L.; Zhang, D.M. Studies on chemical constituents from fruits of Paliurus ramosissimus. Zhongguo Zhong Yao Za Zhi 2006, 31, 2049-2052.

29. Kiseleva, V.V.; Nikonov, G.K.; Karryev, M.O. Structure of diversine and diversinine, coumarins of Ferula diversivittata. Khimiya Prirodnykh Soedinenii 1975, 11, 344-349.

30. CLSI, Clinical and Laboratory Standards Institute (formerly NCCLS, National Committee for Clinical and Laboratory Standards). Reference Method for Broth Dilution Antifungal Susceptibility Testing of Yeasts, Approved Standard M27-A2; National Committee for Clinical and Laboratory Standards: Wayne, PA, 2002; Volume 22 (15).

31. Jorgensen, J.H.; Turnidge, J.D.; Washington, J.A. Antibacterial susceptibility tests: dilution and disk diffusion methods. In Manual of Clinical Microbiology, 7th ed.; Murray, P.R., Faller, M.A., Tenover, F.C., Baron, E.J., Yolken, R.H., Eds.; ASM Press: Washington, D.C., USA, 1999; pp. 1526-1543.

32. CLSI, Clinical and Laboratory Standards Institute (formerly NCCLS, National Committee for Clinical and Laboratory Standards). Performance Standards for Antimicrobial Susceptibility Testing, Eighteenth Informational Supplement; Document M100-S18. NCCLS: Wayne, PA, USA, 2008; Vol. 28 (1), Table 2A-2C.

Sample Availability: Contact the authors.

(C) 2010 by the authors; licensee MDPI, Basel, Switzerland. This article is an Open Access article distributed under the terms and conditions of the Creative Commons Attribution license (http://creativecommons.org/licenses/by/3.0/). 